\title{
CREATING STRATEGIC COMPETENCE OF INDEPENDENT SMALLHOLDERS FOR SUSTAINABLE PALM OIL
}

\section{Mewujudkan Kompetensi Strategis Petani Swadaya untuk Kelapa Sawit Berkelanjutan}

\author{
Nurliza
}

Agribusiness Department, Agriculture Faculty, Universitas Tanjungpura, Pontianak 78124, Indonesia

${ }^{*}$ E-mail: nurliza.spmm@gmail.com

\begin{abstract}
This research was conducted in the frontier districts through in-depth interviews with 120 independent smallholders structured based on the Indonesian Sustainable Palm Oil (ISPO), which include legal aspects, environmental management and monitoring, farmers organization and farm management aspects so that the strategic competence can be translated using both river diagram and stairs diagram. The results indicated that the targets of competency performance initiatives related to legality and environmental management aspects as well as supervision aspects are to learn and receive knowledge practices gradually in all groups of farmers, including knowledge of fire precaution and control and improvement of sustainable businesses. Furthermore, the target of competency performance initiatives related to aspects of fire precaution and control and biodiversity is to receive knowledge transfer. However, regions that have higher competencies or lower competency gaps can be providers of knowledge recipients by considering the technology adoption and appropriate motivation methods. Therefore, in order to overcome farmers' low knowledge and competencies or the high gap between knowledge and competence, there needs to be an approach of capturing knowledge by ensuring that all farmers can learn and are able to access services and innovations; and also an approach of sharing knowledge through education and training programs, proper cultivation practices, certification, and partnerships with universities, companies, governments and communities.
\end{abstract}

Keywords: Independent Smallholders, River Diagram, Stairs Diagram, Strategic Competence, Sustainability

\begin{abstract}
ABSTRAK
Penelitian dilakukan di kabupaten perbatasan melalui wawancara mendalam terhadap 120 petani swadaya dalam kerangka Minyak Kelapa Sawit Berkelanjutan Indonesia (Indonesian Sustainable Palm Oil/ISPO), mencakup aspek hukum, pengelolaan dan pemantauan lingkungan, organisasi petani dan aspek manajemen untuk mewujudkan kompetensi strategis menggunakan diagram sungai dan diagram tangga. Hasil penelitian menunjukkan bahwa target inisiatif kinerja kompetensi terkait aspek legalitas dan manajemen lingkungan serta aspek pengawasan adalah mempelajari dan menerima praktik pengetahuan secara bertahap dalam semua kelompok petani, termasuk pengetahuan terkait tindakan pencegahan dan pengendalian kebakaran dan peningkatan bisnis secara berkelanjutan. Selain itu, target inisiatif kinerja kompetensi terkait aspek pencegahan dan pengendalian kebakaran dan keanekaragaman hayati adalah menerima transfer pengetahuan. Namun, daerah yang memiliki kompetensi lebih tinggi atau kesenjangan kompetensi yang lebih rendah dapat menjadi penyedia penerima pengetahuan dengan mempertimbangkan adopsi teknologi dan metode motivasi yang sesuai. Oleh karena itu, upaya mengatasi pengetahuan dan kompetensi petani rendah atau kesenjangan yang tinggi antara pengetahuan dan kompetensi dilakukan dengan pendekatan menangkap pengetahuan dengan cara memastikan bahwa seтиa petani belajar dan dapat mengakses layanan dan inovasi; dan pendekatan berbagi pengetahuan melalui program pendidikan dan pelatihan, praktik budidaya yang tepat, sertifikasi, dan kemitraan dengan universitas, perusahaan, pemerintah dan masyarakat.
\end{abstract}

Kata kunci: Diagram Sungai, Diagram Tangga, Keberlanjutan, Kompetensi Strategis, Petani Swadaya

Content from this work may be used under the terms of theCreative Commons Atribusi-BerbagiSerupa

4.0 International. Any further distributionof this work must maintain attribution to the author(s) and the title of the work, journal citation and DOI.

Published under Department of Communication and Community Development Science, IPB University

EISSN : 2442-4110 | E-ISSN : 2442-4110 


\section{INTRODUCTION}

Palm oil is a crucial commodity for feeding the growing world population as a result of being the best vegetable oil in the world. Palm oil, the liquid from palm oil, is mostly used by households (e.g. cooking oils) and the world industries (e.g. personal care and cosmetics, retail food and snack manufacturers, biofuel and energy, animal feed, pharmaceutical, and food service/industry service). Furthermore, palm oil attracts farmers as it generates wealth and sustainable improvement, as well as employment for local communities. Around 16 million of indirect jobs were available in this sector. The land-use profitability analysis also showed higher returns and higher competitiveness than rubber; it is far more feasible and more economic than rice production (Feintrenie et al. 2010).

However, there was a debate on the palm oil sector, which had a negative impact, i.e. land alienation, social and politic conflicts, labor exploitation, degraded land, water pollution and damage of biodiversity (Feintrenie et al. 2010), which become a public issue for the government, parliaments and citizens in many countries, particularly to guarantee the standards for sustainable production. Thus, the WTO's Trade and Environment Committee has been committed to ensuring production systems with appropriate standards to strengthen the environmental and farmers' will use these standards scheme framework for catching world market for the palm oil's future and its sustainability.

Therefore, Indonesia as the world palm oil producer launched Indonesia's Sustainable Palm Oil System or ISPO in 2011 as the mandatory certification scheme. Furthermore, the Ministry of Agriculture, with UNDP support, has taken the lead to analyze major differences between ISPO and RSPO to align the principles and criteria of ISPO, to strengthen its legal standing in the sustainability dimensions and public policy involvement, and to counter the risk that probably arises. However, an appropriate standard alone is not the answer, and all the initiatives undertaken need a platform to discuss due to the complex and interconnected issues along the value chain by enhancing coordination and building consensus.

In parallel, it is also importunate to support independent smallholders who already manage more than 40 percent of all palm plantations in Indonesia, which face a tough challenge due to the following aspects underlined in the RSPO (2016) and the Agriculture Ministry for palm oil license (No.98/Permentan/OT.140/9/2013). Independent smallholder's common characteristics are selforganized, self-managed, self-financed, and no formal sustainability requirements, which caused ineligible for ISPO standard. Meanwhile, sustainable palm oil industry required the organized farmers groups to receive a training and access to strategic agricultural resources for the certification. Besides, they also varied greatly and had lower productivity than plasma farmers.

Recently, emerging sustainability research has tried to explore the learning outcomes and competency development for farmers as change agents through active participation modeling and transforming society towards sustainable practices to help in bridging the gap between performance and opportunity. It also hopes to help farmers use ISPO standards voluntarily by linking traditional business to products and future service to obtain more opportunities across the market and the products as a long term competitive advantage. The farmers ought to specialize in outsourcing all noncore activities to improve the operations and encourage learning setting appropriate for their competencies. The important aspect of the competencies will provide a framework for identifying farmers' strengths and strategies accordingly.

Thus, this research tried to translate the strategic competence of independent smallholders' ability through gaps identification between knowledge and competence in ISPO framework for controlling their work and nurturing an acceptable response level of the confront contingencies. However, the challenge is how to identify, hold onto, share, and evolve the accurate and reliable critical gaps between knowledge and competency for emerging the competitive advantage and avoid the redundancies or scarcity of the competencies.

\section{METHODS}

It was necessary to identify the characteristics of the respondent for providing an overview that formed the results of the strategic competence analysis and their effect on competences (Islam. et al. 2013; Kuipers et al. 2014; Montedo \& Abrahão, 2015; Vik \& Stræte, 2017). The respondents' 
characteristics also provided effective adoption and transfer of technical knowledge (Euler et al., 2015). Therefore, the results confirmed that (1) the majority of the independent smallholders were 1755 years old; (2) the average education level of household heads was elementary school; (3) their land tenure was from 2 to 4 hectares; (4) the number of family members was $4-5$ person; (5) the farm experience was 7-9 years; (6) the number of palm oil trees was less than 200; (7) the age of the palm oil farm was 4-5 years; and (7) their monthly yield was less than 2 tons/ha. These can be seen in Table 1.

Table 1. The characteristics of respondents

\begin{tabular}{|c|c|}
\hline & Percentage $(\%)$ \\
\hline \multicolumn{2}{|l|}{ Age (years): } \\
\hline$<17$ & 0 \\
\hline $17-55$ & 71.7 \\
\hline$>55$ & 28.3 \\
\hline \multicolumn{2}{|c|}{ Education of household head: } \\
\hline Illiterate & 14.2 \\
\hline Elementary school & 32.5 \\
\hline Junior high school & 27.5 \\
\hline Senior high school & 15.8 \\
\hline College & 10.0 \\
\hline \multicolumn{2}{|l|}{ Land tenure (hectares): } \\
\hline$\leq 2$ & 70.0 \\
\hline$>2-4$ & 20.8 \\
\hline$>4-6$ & 4.2 \\
\hline$>6-8$ & 2.5 \\
\hline$>8$ & 2.5 \\
\hline \multicolumn{2}{|c|}{ Family members (persons): } \\
\hline $1-3$ & 31.7 \\
\hline $4-5$ & 61.7 \\
\hline $6-7$ & 6.6 \\
\hline \multicolumn{2}{|c|}{ Farm experiences (years): } \\
\hline $4-6$ & 21.7 \\
\hline $7-9$ & 67.5 \\
\hline $10-12$ & 10.0 \\
\hline $13-15$ & 0.8 \\
\hline \multicolumn{2}{|l|}{ Number of trees: } \\
\hline$\leq 200$ & 49.2 \\
\hline$>200-400$ & 28.3 \\
\hline$>400-600$ & 14.2 \\
\hline$>600-800$ & 3.3 \\
\hline$>800$ & 5.0 \\
\hline \multicolumn{2}{|l|}{ Age of palm oil (years): } \\
\hline $8-9$ & 4.2 \\
\hline $6-7$ & 36.7 \\
\hline $4-5$ & 59.1 \\
\hline \multicolumn{2}{|c|}{ Monthly yields (tons/ha): } \\
\hline$<2$ & 60.8 \\
\hline $2-4$ & 29.2 \\
\hline$>4-6$ & 5.0 \\
\hline$>6-8$ & 3.3 \\
\hline$>8$ & 1.7 \\
\hline
\end{tabular}

In Table 1, considering their average age, the independent smallholders were in their productive level, but their education was low. Thus, it is difficult to access the information for adjusting the management requirement in order that the adoption of plant management rates remain 
less to moderate. Meanwhile, the farming experience is a proxy for the age of farmers reflecting the successful compliance of new plantation crop (Euler et al., 2015). With regard to land tenure, the majority of farmers had over two ha and less than four ha due to land claim history (Krishna et al., 2014). Most of them managed and monitored their farm as a path-dependency (Jelsma et al., 2017). Palm oil keeps spreading over forests and displacing rubber plantations and Siam orange which are common commodities in Sambas or frontier area due to significantly high financial return income parallel with the farm sizes. Afterwards, the expansion of palm oil production grew at a slower rate due to the absorption capacity boundary of existing processing plants and free land resources scarcity. The land conversion to palm oil seems unfavorable to everyone (Euler et al., 2015). Moreover, the Land Agency in Sambas regency only issued a land ownership certificate (SHM) by owning land ownership letter (Surat Keterangan Tanah/SKT) from their head of village (lurah). Still, there are some farmers reported of being reluctant to obtain land ownership certificate due to some concerns about tax of land ownership certificate, and limited funds for processing fee, unless there are some benefits of having it (INOBU, 2016).

Regarding the family members, the majority of palm oil households had 4-5 persons, which serve as workforce to support families and minimize labor cost due to higher costs or capital and input-intensive. The switching of labor from rubber to palm oil due to land conversion to palm oil from rubber which is less labor-intensive can be used to increase off-farm incomes (Euler et al., 2017). Furthermore, the number of palm oil trees, the age of palm oil plant, and the yield illustrated that the productivity of independent smallholders is far below but has larger variation than plasma farmers and private plantation (Daemeter-Consulting, 2015) caused by insufficiency of farm management knowledge and short of financial capital, i.e. uncertified seed, incorrect planting distance, pruning, weed control, pest management, and proper fertilizers (Euler et al., 2016). Hence, the results of competency assessment in legal and environmental management and monitoring aspects are used for identifying the strengths and weakness as an integrated strategic approach, to create a strategy of sharing knowledge within an organization using the stair diagram presented in Figure 1 and Figure 2.

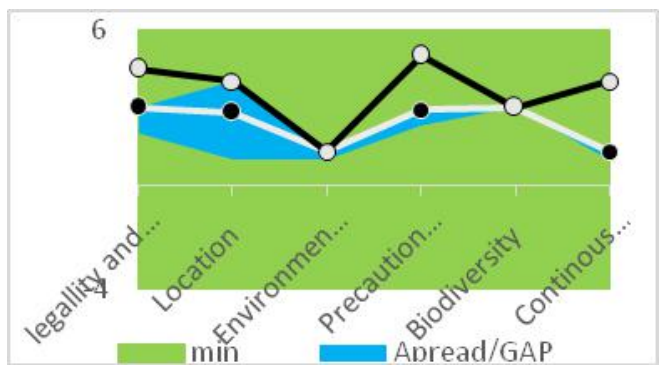

(a) Paloh (district 1)

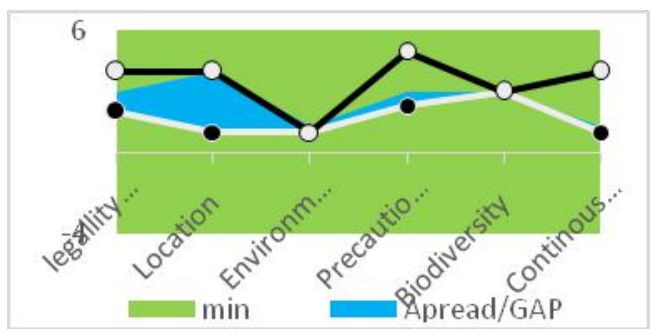

(c) TelukKeramat (district 3)

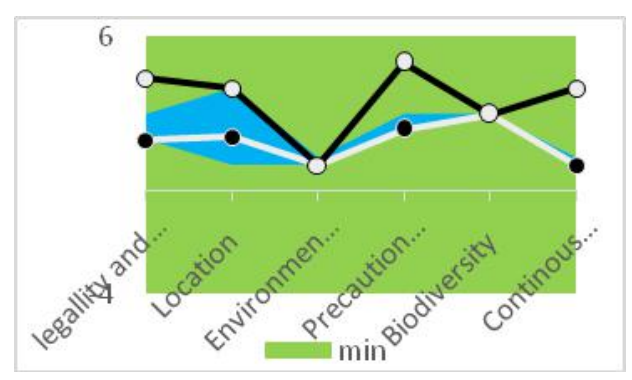

(b) Sejangkung (district 2)

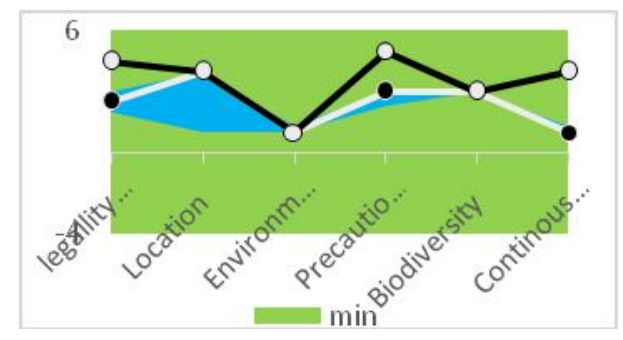

(d) Subah (district 4)

Figure 1. River diagram assessment of legal and environmental management \& monitoring aspects

In Figure 1, the assessment of legal and environmental management and monitoring aspects in some districts proved that the competences were above average, i.e. legal and management (district 1); location (district 4); the precaution and control of fire (district 1 and 4); biodiversity (district 1). Regarding the legal and management, the competence was supported by the role of farmer's organization for serving their members in making input and output markets (Shiferaw et al., 2009; 
Barham \& Chitemi, 2009; UNSDSN, 2013). The farmer organizations could be directly linked to the markets with non-governmental organizations support (Hellin et al., 2007) to achieve sustainable development goals (Kumar et al., 2015; Nurliza\& Dolorosa, 2017), poverty reduction and rural development (Penunia, 2011; FAO, 2012), and the value chain integration (Francesconi \& Wouterse, 2015).

The changes in location knowledge can be attributed to achievingself-sufficient farming (Tripp \& Longley, 2006), and the palm oil processing locations that are close to farmers' land with the suffice road of access have a potential effect on reducing the reliance upon the cost of distance and pursuing a profitable livelihood option (Cramb \& Sujang, 2012; Cazzola et al., 2013). Meanwhile, palm oil on peat lands had an impact on the peat's ecosystem and financial due to the characteristics of fire- prone peat lands (Varkkey, 2015; Veloo et al., 2015) which need related expertise of planning and best management practice (Goldstein, 2016).

Still, most farmers plant some catch and green crops cover (Pe'er et al., 2016) for farming practices which are often misperceived as farmland biodiversity or the ecological protection. However, most of the references proved that the ecological factors are needed as key factors in the policy environment for the biodiversity (Yves et al., 2017). Moreover, most land in palm oil research areas is land conversion from several different land use types, such as rubber, Siam orange and rice fields, leading to indirect land use change effects (Saswattecha et al., 2016). It is also exacerbated by current moratorium conversion of production forests which resulted in biodiversity threat and increased greenhouse gas emissions, even though there are some tax and policies for protecting the conservation areas (Vijay et al., 2016). The adoption of majority independent smallholders in legal and environmental management and monitoring aspects was illustrated in Figure 2.

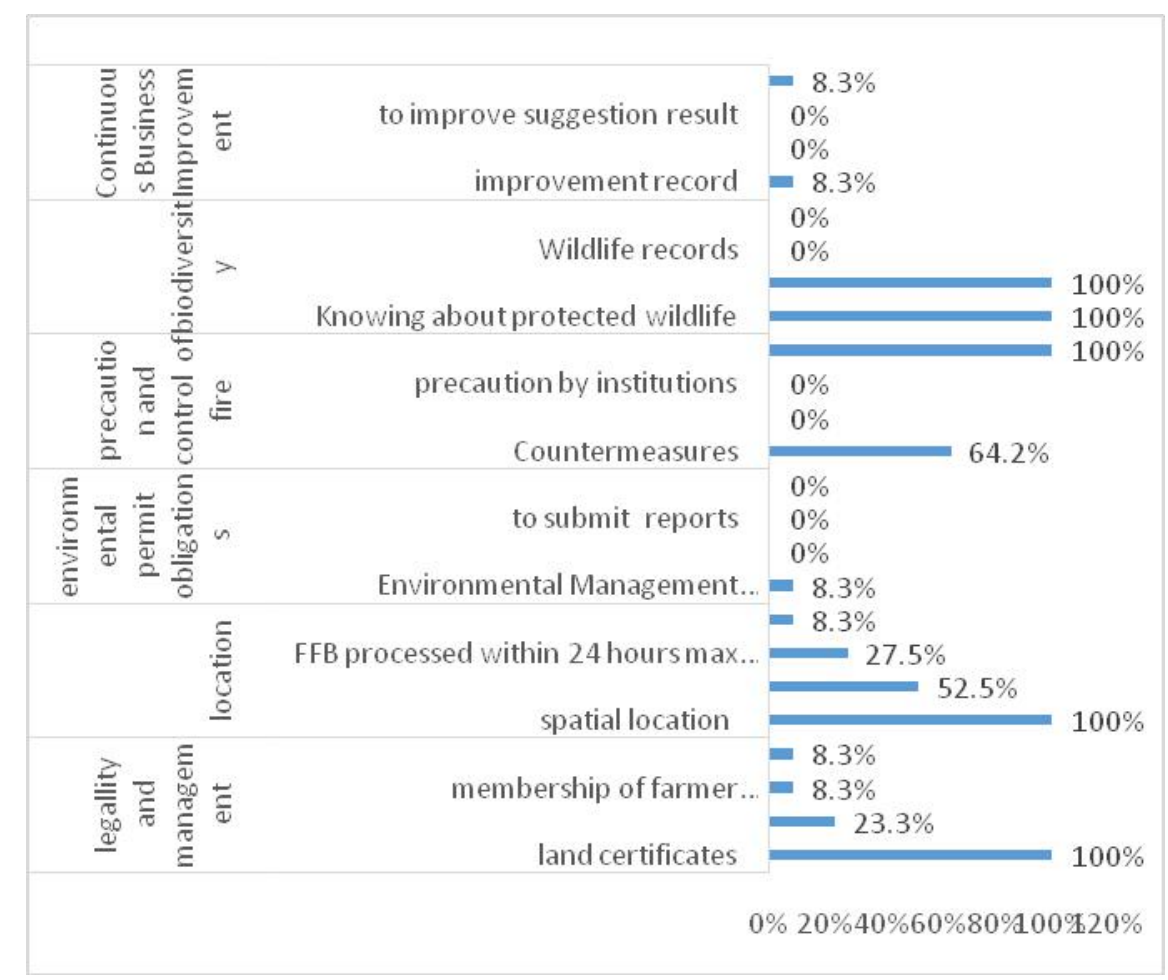

Figure 2 The adoption frequency in legal and environmental management and monitoring aspects

In Figure 2, the adoption frequency of legality and environmental management aspects as well as supervision aspects is low, due to the following aspects. First, there was no record of continuous business improvement due to no modular training by agricultural consulting services (Wordofa \& Sassi, 2014), constraints along the value chain market (Baloyi, 2010), extension programs with commercial interests, limited risk management and investment (IDH, 2017). Second, farmers had limited information and proper cultivation practices, and there was no record of the implemented sustainable business improvement results. Second, records of fire precaution and control are low due to limited 
access, understanding and credibility of information in context-specific decision making (Nesheimet.al. 2017), as well as an unbalanced proportion between commitments and obligations within the ISPO framework. Therefore, the local governments must be able to maintain and enhance policies that expand access to certain public services by supporting access to basic needs and other supporting factors. A multi-year strategy for implementing various obligations and bound rights is needed to gain the benefits of ISPO compliance (Joseph, 2013). Third, there were no environmental management records due to lack of awareness, low effectiveness and transparency, and low technological innovation (OECD, 2005), such as the confusing proliferation of laws, difficulties in compliance, no modern management information and technical solutions, limited technical skills, and financial resources in management and technology solutions, as well as skeptical perspectives on profit potential, cost savings, and client rewards in environmental improvements (OECD, 2007; Munthali \& Murayama, 2013). Fourth, there were records of institutional activities due to farmers' heterogeneity and lack of linkages between commercial agriculture, production and marketing, which causes uncoordinated decision making; depository practices that are not in line with commercial approaches; limitations in managing and understanding quality; and sales to intermediaries (middlemen), fund deviations and personal profit motivations (Woolverton \& Neven, 2014).

On the other hand, farmers' competence in legal and management aspects related to land certificates is higher due to the positive effect of registration and certification of rural agricultural household land (Taddese, 2013). Therefore, the institutional function of farmers in the future should become a center for knowledge transfer by improving the structure and eliminating the institutional costs. Fifth, there were no records of wild plants and animals (biodiversity) due to differences between farmers' perceptions of damage and compensation objectively and rationally from conservation policies. Thus, a visual damage assessment technique is needed by the government to pay compensation to farmers (Bayaniet.al. 2016). However, competence related to spatial location to support biodiversity is proven to be higher than other aspects so it requires a comprehensive approach through a participatory process of area design to understand ecosystem services. Mapping, calculation, and graphics as communication tools are used to design possible implications for the loss of biodiversity in the future (Rojoet.al. 2014). In legal and management section, the smallholders' competence of land certificates is also found to be higher due to positive and significant effect on the registration and certification of land in rural farm households to engage in the planting (Taddese, 2013). The results of competence assessment in farmers' organization and farm management aspects were presented in Figure 3 and Figure 4.

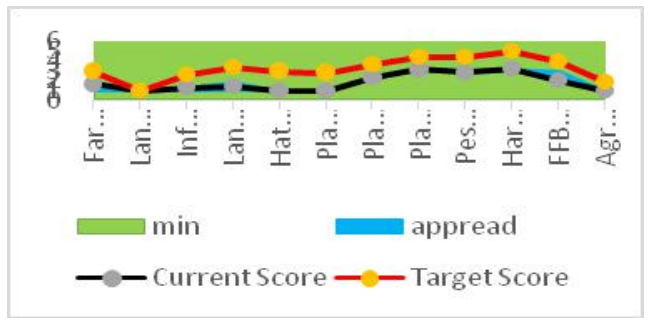

(a) Paloh (district 1)

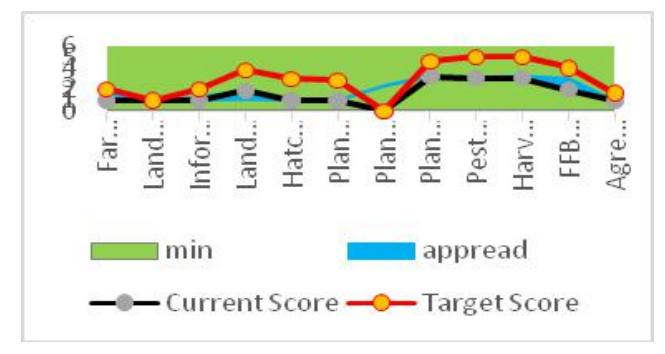

(c) Teluk Keramat (district 3)

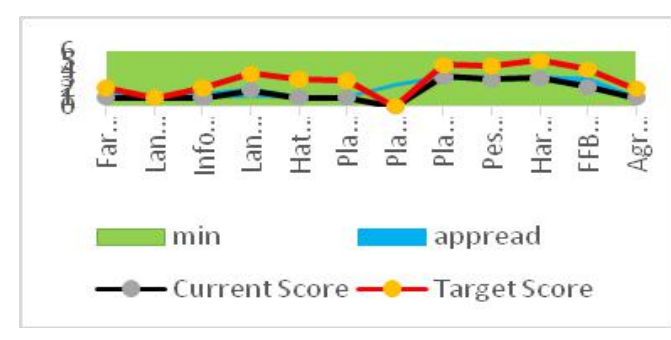

(b) Sejangkung (district 2)

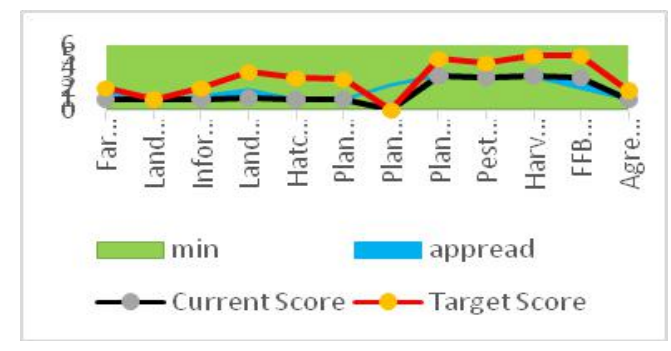

(d) Subah (district 4)

Figure 3. River diagram for assessing farmers' organization and farm management aspects 
In Figure 3, the majority of districts had low competence except the following: i.e. the plant cultivation (district 1 and district 2) which is the key to the sustainability of the platform of palm oil production to conserve high value of forests and wild life (Basiron, 2007), harvesting (district 1 and district 2) and FFB transportation (district 4) regarding the quality of fresh fruit bunches (FFB) (Mat Sharif et al., 2017), and the efficiency of work and financing (Salmiyati et al., 2014) as presented in Figure 4.

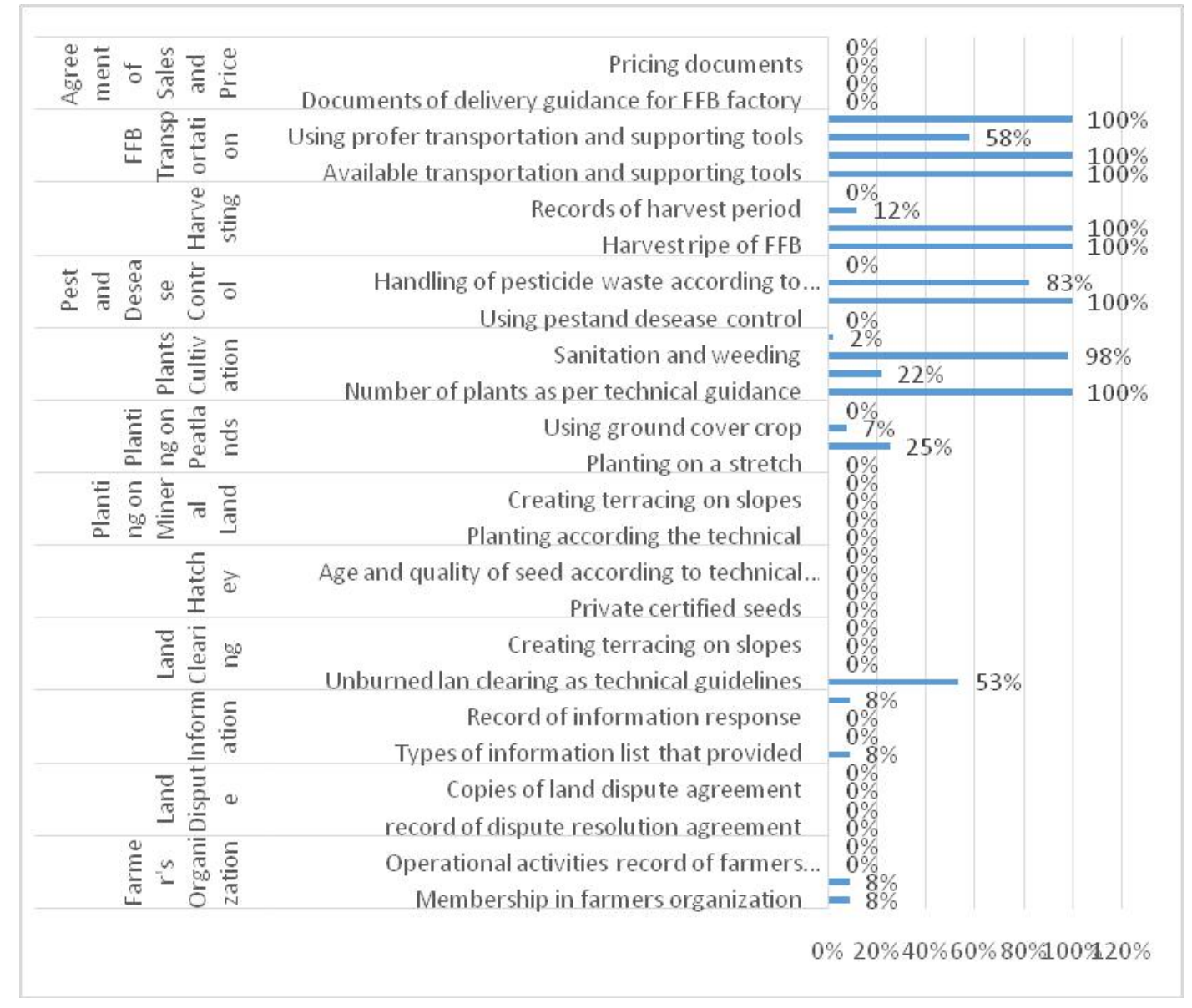

Figure 4. The adoption frequency in farmers' organization and farm management aspects

In Figure 4, most adoption frequency in farmer organizations and farm management aspects was very low and even there was no adoption, mainly related to several aspects: (1) Harvesting (harvest period records); (2) Plant cultivation (records of crop cultivation, maintenance of terraces and drainage, etc.); (3) Planting on peat lands (use of ground cover, number and spacing according to instructions); (4) Information (information and types of information provided); (5) Farmer Institution (records of establishment and membership) as a significant problem for policy formulation and the program planning, and monitoring and evaluation (Tham-Agyekum et al., 2010). Therefore, the cotraining with economic incentives to increase awareness of their benefits under certain conducive terms might be able to deliver competitive and effective cost and tools for desired goals (Hong Yun \& Lian Ge, 2009).

The independent smallholders also remains unclear about ISPO due to the vague status of the certification process (van der Enden, 2013), which leads to a different path of policy arrangements and reshaped power relations for each of the villages. The policy makers should consider the dynamics in the given context and site awareness amongst the frontier smallholders about the farm management in ISPO principles and criteria which seems to be very limited. Several smallholders acknowledged that a higher price of FFB involved the compliment of ISPO certification, which is certainly no guarantee. Farmers' organization and farm management aspects assessment also proved that there is still very low adoption or low competence regarding the harvesting section (i.e. records of 
harvest period); plant cultivation section (i.e. records of plant cultivation, terracing maintenance and drainage, etc.); planting on peat lands (i.e. using ground cover crop, set number and spacing as per instructions); information section (i.e. information and type of information list that is provided); andfarmers organization section (i.e. establishment record of and membership). Otherwise, the highest competencies would be long affordable between the estate and processing plant, record of total transportation, available transportation and supporting tools in the FFB transportation section; preparation of manpower, equipment and tools, ripe of FFB harvest in harvesting section; listed pesticides in the pest and disease control section; and number of plants as per technical guidance in plants cultivation section.

However, there are some major competences, i.e. using proper transportation and supporting tools in the FFB transportation section; handling waste pesticides according to technical guidance in the pest and disease control section; sanitation and weeding in the plant cultivation section; and unburned land clearing as technical guidance in land clearing section. This is a potential impact of palm oil cultivation on peat lands, such as subsidence of soil, flooding, pollution of water and water, biodiversity change and socioeconomic (Huan et al., 2012). Besides, there are some characteristics of palm oil farming in peat lands areas by independent smallholders, i.e. comparatively high costs due to additional land preparation and water management or physical and production infrastructure; comparatively high risks due to access to production inputs and fire and pests control, low productivity (Gaveau et al., 2014; Lim et al., 2012; Woittiez et al., 2017), and off-farm economic opportunities and public services which are less than established agricultural area. However, the land prices tend to be considerably lower, making it attractive for land speculation.

Therefore, the empirical findings generally reveal that the low competencies caused innovative technology usage barriers tothose services because of the following reasons, i.e. lack of the existence of such technologies or lack of information access among farmers (Odongo, 2014); erratic and poor service delivery (Wild et al., 2012; Obert et al., 2015); inadequacy of the provided services (Odini, 2014); inadequate number of extension officers (Baloch \& Thapa, 2019); low service, motivation, and sense of responsibility among extension agents, also weak monitoring system (Jan et al., 2008); and lack of access to finance (Wulandari et al., 2017). Furthermore, the result of competence assessment in legal and environmental management and monitoring aspects as a strategic tool can be used to promote community groups for providing ideas of potential competences, which can be shared gradually using stair diagrams as presented in Figure 5 and Figure 6.
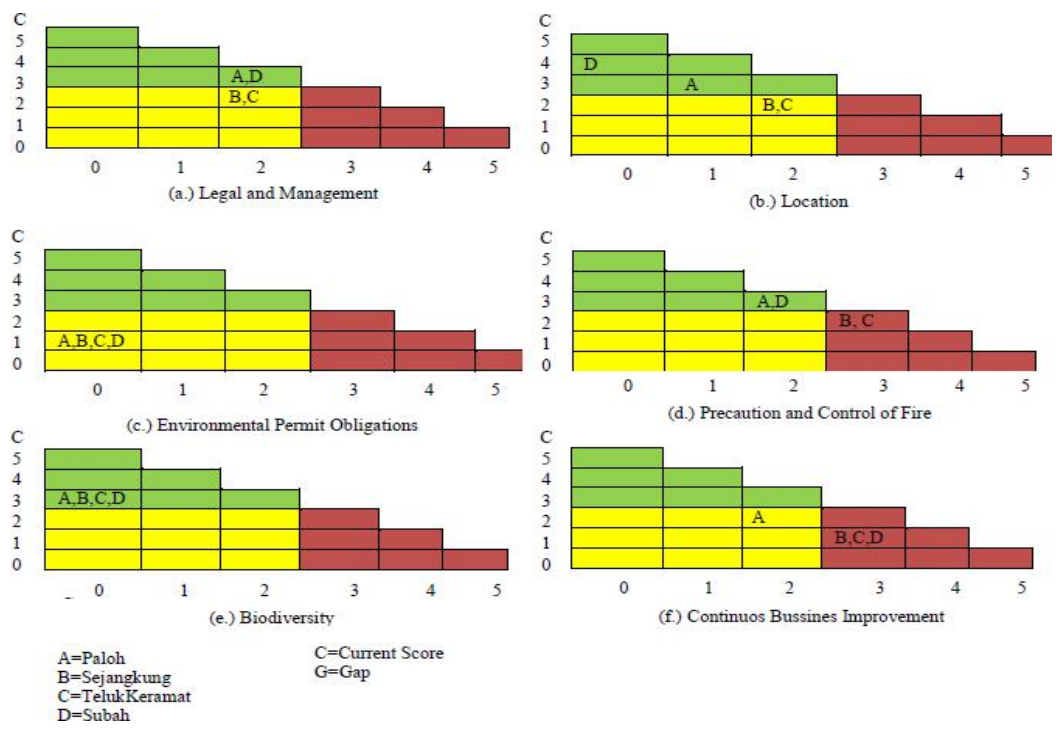

Figure 5. Stair diagram for assessing legal and environmental management $\&$ monitoring aspects

In Figure 5, farmer groups are in the lower right side. They are those who have low competencies at the current score but are considered as a group with a great opportunity to learn and receive knowledge, especially in the precaution and control of fire aspects (district 2 and district 3 ) 
and continuous business improvement aspects(all of district). On the other hand, farmer groups in the upper left are those who have higher competencies at the current score, or the target difference to be achieved is low, so that the group has higher knowledge and competence than others, especially in legal and management aspects (district 1 and district 4); location (district 1 and district 4); precaution and control of fire (district 1 and district 4); and biodiversity (all districts). Then, the yellow groups are farmer groups who have less competence, so that they can only become groups of recipients of knowledge and skills for all aspects, except for precaution and control of fire, and alsobiodiversity.

Thus, the target competence performance initiative of legal and environmental management and monitoring aspects for learning and receiving the best knowledge practice gradually in the whole group are the precaution and control of fire and continuous business improvement aspects. Furthermore, the target competence initiative performance for sharing of the best knowledge practice gradually in the whole groups are legal and management aspects, and also the location aspect. On the other hand, the target competence initiative performance for practicing in the whole group as recipients in transfer knowledge are the precaution and control of fire, and biodiversity aspect. However, district 1 and district 4 had higher competence at the current score or lower gaps of competence and can be transformed into a provider of recipient of knowledge depending on the technology adoption methods and the motivation.

In Figure 6, farmer groups in the lower right are those who have low competencies at the current score, but are considered as a group with a great opportunity to learn and receive knowledge, especially in the land clearing aspect (all districts); hatchery (all districts); planting on mineral land (all districts); plant cultivation (district 4); pest and disease control (district 1, district 2 and district 3); harvesting (all districts); and FFB transportation (all districts). The farmer groups in the upper left are those who have higher competencies at the current score, or the target difference to be achieved is low, so that the group has higher knowledge and competence than others. However, there are no areas with those competencies. The yellow areas are the farmer groups who have less competence, so that they can only be recipients of knowledge and skills, particularly in farmers organization and farm management aspects for all districts, except for land clearing, hatchery, planting on land mineral, harvesting, and FFB transportation.

Thus, the target competence initiative performance of farmers' organization and farm management aspects for learning and receiving the best practice knowledge gradually in the whole group is the aspect of land clearing (all districts); hatchery (all districts); planting on mineral land (all districts); plant cultivation (district 4); pest and disease control (district 1, district 2 and district 3); harvesting (all districts); and FFB transportation (all districts). Meanwhile, the target competence of initiative performance in transferring the best knowledge practices is all aspects of farmer organizations and farm management for the whole groups, except for the aspects of land clearing, hatchery, planting on land mineral, harvesting and FFB transportation. 


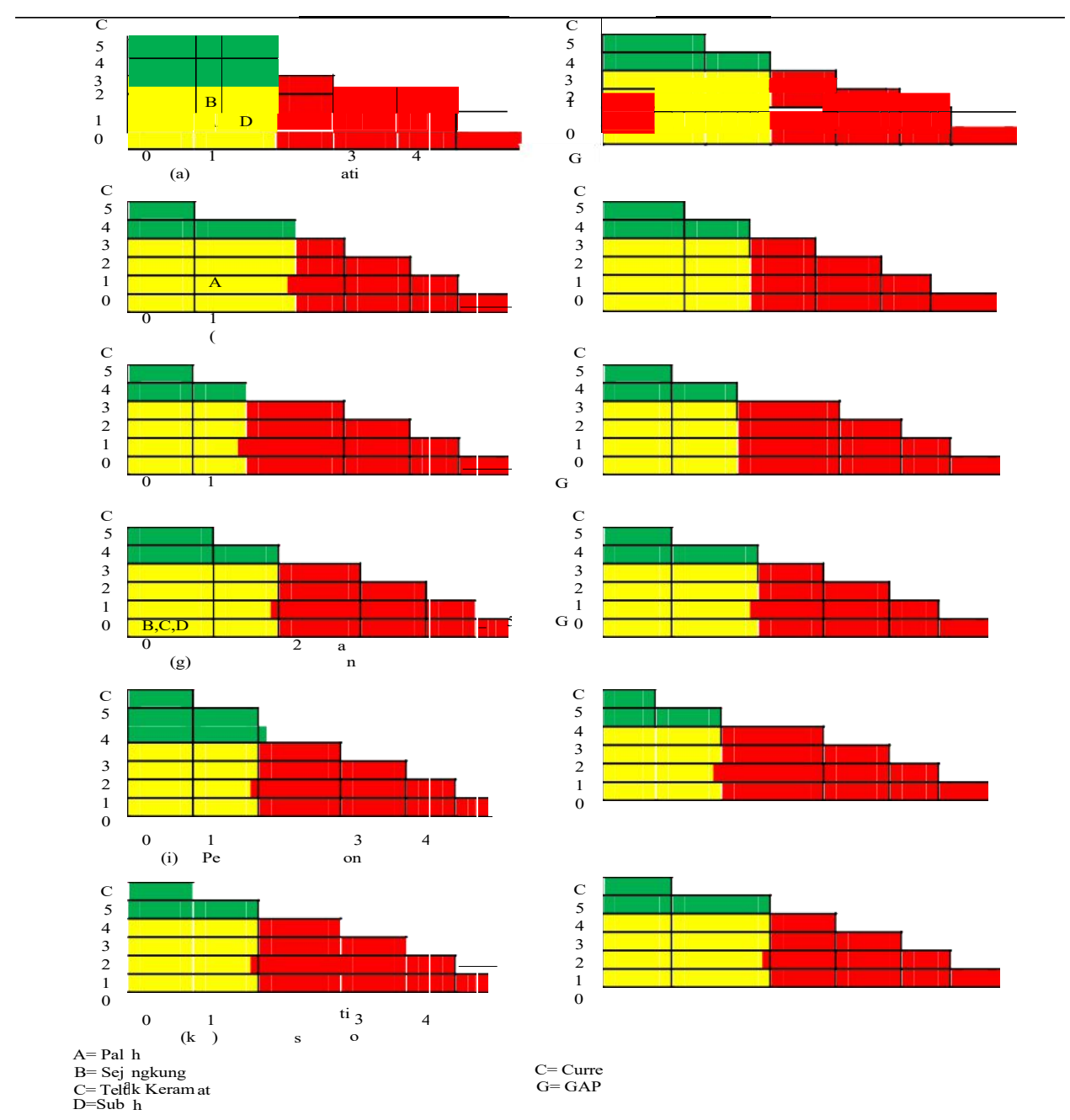

Figure 6. Stair diagram for assessing farmers' organization and farm management aspects 
There has been a demand for effective linkages among the extension centers and stakeholders in problem-solving and decision-making processes, and disseminating knowledge, skills, and information (Glendenning et al., 2010; Kahan, 2013) to address the specific location constraints and significant positive roles' of speed adoption in the palm oil export price as market incentives (Wheeler et al., 2013; Euler et al., 2015; Shepherd, 2007; Baloch \& Thapa, 2016) by adapting to climate change (Anwar, et al., 2013). Therefore, there are two highlights for those problem results, i.e. knowledge capture and knowledge sharing to ensure the delivery of outstanding service and innovation for all smallholders to access insights and learning of the competence and knowledge. In knowledge capture, it can be achieved through digital boost for supporting materials, including online library of manuals and tutorial videos. The platform allows for benchmarking data so that they can always improve their practices and achieve sustainability certification for their crops. Knowledge sharing is achieved through fields of smallholders' projects and creating education hubs, providing training programs and good practices, ISPO training and certification, creating relationships with mills and farmer groups, and partnership with local schools, universities, and local NGOs for palm oil future sustainability industries.

\section{CONCLUSIONS}

The assessment of legal and environmental management and monitoring aspects prove that the competence and adoption frequency are above average, but there is a lack of adoption in legal and environmental management, and monitoring aspects. Farmers' organizations and farm management aspects assessment also proved that the adoption or competence is still very low. However, there are some major competencies, i.e. using proper transportation and supporting tools in the FFB transportation section; handling waste pesticides according to technical guidance in the pest and disease control section; sanitation and weeding in the plant cultivation section; and unburned land clearing as technical guidance in land clearing section. Thus, the target competence performance initiative of legal and environmental management and monitoring aspects for learning and receiving best knowledge practice gradually in the whole group are the precaution and control of fire and continuous business improvement aspects. The target competence initiative performance for sharing the best knowledge practice gradually in the whole groups is legal and management aspects, and also the location aspect.

Meanwhile, the target competence initiative performance for practicing in the whole group as recipients in transfer knowledge includes the precaution and control of fire, and also biodiversity aspect. Then, the target competence initiative performance of farmers' organization and farm management aspects for learning and receiving best knowledge practice gradually in the whole group is the aspect of land clearing; hatchery; planting on mineral land; plant cultivation for some districts; pest and disease control for some districts; harvesting; and FFB transportation. All aspects of farmer organizations and farm management are the target competence initiative performance in transferring the best knowledge practices gradually in the whole groups, except for the aspects of land clearing, hatchery, planting on land mineral, harvesting and FFB transportation in all districts. There are districts with higher competence at the current score or lower gaps of competence so that they can be transformed into a provider of recipient of knowledge depending on the technology adoption methods and the motivation. Therefore, there are two highlights for those problem results, i.e. knowledge capture and knowledge sharing to ensure the delivery of outstanding service and innovation for all the smallholders to access insights and learning of the competence and knowledge.

\section{ACKNOWLEDGEMENTS}

The researcher would like to thank the Directorate of Research and Community Service, Directorate General for Strengthening Research and Development of the Ministry of Research, Technology (RISTEK) and Higher Education (DIKTI) for funding this research through the applied research scheme 2019-2021. 


\section{REFERENCES}

Alshenqeeti, H. (2014). Interviewing as a data collection method: A critical review. English Linguistics Research. 3(1), 39-45.

Anwar, M. R., Liu, D. L., Macadam, I., \& Kelly, G. (2013). Adapting agriculture to climate change: A review. Theor Appl Climato. 113, 225-245.

Baloch, M. A., \& Thapa, G. B. (2016). The effect of agricultural extension services: Date farmers' case in Balochistan, Pakistan. Journal of the Saudi Society of Agricultural Sciences. 05(7). doi: org/10.1016/j.jssas.2016.05.007.

Baloch, M. A., \& Thapa, G. B. (2019). Review of the agricultural extension modes and services with the focus to Balochistan, Pakistan. Journal of the Saudi Society of Agricultural Sciences, 18(2), 188-194.

Baloyi, J. K. (2010). An Analysis of Constraints Facing Smallholder Farmers in The Agribusiness Value Chain: A Case Study of Farmers in The Limpopo Province.Pretoria(South Africa): University of Pretoria.

Barham, J., \& Chitemi, C. (2009). Collective Action Initiatives to Improve marketing

Performance: Lesso from Farmer Groups in Tanzania. Food policy, 34(1) , 53-59.

Basiron, Y. (2007). Palm oil production through sustainable plantations. European Journal of Lipid Science and Technology. 109(4), 289-295.

Bayani, A., Tiwade, D., Dongre, A., Dongre, A. P., Phatak, R., \& Watve, M. (2016). Assessment of crop damage by protected wild mammalian herbivores on the western boundary of TadobaAndhari Tiger Reserve (TATR), Central India. PLoS One 11(4), doi: 10.1371/journal.pone.0153854.

Cazzola, P., Morrison, G., Kaneko, H., Cuenot, F., Ghandi, A., \& Fulton, L. (2013). Production Costs of Alternative Transportation Fuels: Influence of Crude Oil Price and Technology Maturity. Paris (FR): The International Energy Agency.

Cramb, R. A., \& Sujang, P. S. (2012). Pathways through the Plantation: Oil Palm Smallholders and Livelihood Strategies in Sarawak, Malaysia. The $56^{\text {th }}$ AARES annual conference, February $7^{\text {th }}$. $10^{\text {th }}, 2012$ (p. 1-30). Fremantle, Western (AU): Australian Agricultural \& Resource Economics Society.

Daemeter-Consulting. (2015). Overview of Indonesian Oil Palm Smallholder Farmers: A Typology of Organizational Models, Needs, and Investment Opportunities. Bogor (ID): Daemeter Consulting.

Euler, M., Hoffmann, M. P., Fathoni, Z., \& Schwarze, S. (2016). Exploring yield gaps in smallholder oil palm production systems in Eastern Sumatra, Indonesia. Agricultural Systems. 146, 111-119.

Krishna, V., Schwarze, S., Siregar, H., \& Qaim, M. (2017). Oil palm adoption, household welfare, and nutrition among smallholder farmers in Indonesia. World Development. 93, 219235.

, Schwarze, S., Siregar, H., \& Qaim, M. (2015). Oil Palm Expansion Among Smallholder. Göttingen(Germany): EFForTS, Ecological and Socioeconomic Functions of Tropical Lowland Rainforest Transformation Systems.

FAO. (2012). Agricultural cooperatives: paving the way for food security and rural development. Rome, Italy (IT): Food and Agriculture Organization of the United Nations.

Feintrenie, L., Chong, W. K., \& Levang, P. (2010). Why do farmers prefer oil palm? Lessons learnt from Bungo district, Indonesia. Bogor (ID): Center for International Forestry Research.

Francesconi, G. N., \& Wouterse, F. (2015). Promoting the role of farmer-based organizations for value chain integration: The tension between a program's targeting and an organization's investment strategy. Agricultural Economics. 46(4), 527-536.

Gaveau, D. L., Sloan, S., Molidena, E., Yaen, H., Sheil, D., Abram, N. K., et al. (2014). Four Decades of Forest Persistence, Clearance and Logging on Borneo. PLoS ONE, 9(7) , 1-11.

Glendenning, C. J., Babu, S., \& Asenso, K. (2010). Review of Agricultural Extension in India: Are Farmers' Information Needs Being Met? Washington (US): International Food Policy Research Institute.

Goldstein, J. O. (2016). Knowing the subterranean: Land grabbing, oil palm, and divergent expertise in Indonesia's peat soil. Environment and Planning A. 48(4), 754-770.

Hellin, J., Lundy, M., \& Meijer, M. (2007). Farmer organisation and market access.Leisa Magazine (Netherlands), 23(1), 26-27. 
Hong Yun, H., \& Lian Ge, Z. (2009). Farmer characters' and behaviour of fertilizer applicationEvidence from a survey of Xinxiang County, Henan Province, China. Agricultural Sciences in China. 8(10), 1238-1245.

Huan, L. K., Lim, S. S., Parish, F., \& Suharto, R. (2012). RSPO Manual on Best Management Pratices (BMP's) for Existing Oil Palm Cultivation on Peat. Kuala Lumpur (--): RSPO.

Islam, I., Hoque, M. J., Momen Miah, M. A., \& Sheheli, S. (2013). Competency assessment of the farmers on the apllication of one house one farm approach. Progress. Agric. 24(1\&2), 291-299.

IDH. (2017). Transforming Agriculture Business Models To Improve Profitability And Livelihoods: A breakthrough in smallholder engagement. The Netherland: IDH the Sustainable Trade Initiative.

INOBU. (2016). A Profile of Oil Palm Smallholders and Their Challenges of Farming Independently. San Francisco, California (US): Institut Penelitian Inovasi Bumi.

Jan, I., Khan, H., \& Jalalu, M. (2008). Analysis of agricultural extension system: A discrepancy between provider and recipients of the extension services empirical evidence from North-West Pakistan. Sarhad J. Agric. 24(2), 349-354.

Jelsma, I., Schoneveld, G. C., Zoomers, A., \& A., C. v.(2017). Unpacking Indonesia's independent oil palm smallholders: An actordisaggregated approach to identifying environmental and social performance challenges. Land Use Policy. 69, 281-297.

Joseph, S. (2013). Blame It on the WTO? A Human Rights Critique. Oxford (GB): Oxford University Press.

Kahan, D. (2013). The role of the Farm Management Specialist in Extension. Rome (IT): Food and Agriculture Organization of the United Nations.

Krishna, V. V., Pascual, U., \& Qaim, M. (2014). Do emerging land markets promote forestland appropriation? Evidence from Indonesia. Goettingen (--): EFForTS Discussion Paper 7, Georgia University of Goettingen.

Kuipers, A., Rozstalnyy, A., \& Keane, G. (2014). Cattle Husbandry in Eastern Europe and China: Structure, Development Paths and Optimisation. The Netherlands (--): Wageningen Academic Publishers.

Kumar, V., Wankhede, K. G., \& Gena, H. C. (2015). Role of cooperatives in improving livelihood of farmers on sustainable basis. American Journal of Educational Research. 3(10), 1258-1266

Lee, J. H., Nam, S. K., Kim, A.-R., Kim, B., Lee, M., \& Lee, S. M. (2013). Resilience: A Meta-Analytic Approach. Journal of counseling and development, 91(3) , 269-279.

Lim, S. S., Vos, T., Flaxman, A. D., Danaei, G., Shibuya, K., Adair-Rohani, H., et al. (2012). A comparative risk assessment of burden of disease and injury attributable to 67 risk factors and risk factor clusters in 21 regions, 1990-2010: A systematic analysis for the Global Burden of Disease Study 2010. Lancet, 380, 2224-2260.

Mack, N., Woodsong, C., MacQueen, K. M., Quest, G., \& Namey, E. (2011). Qualitative Research Methods: A Data Collector's Field Guide. North Carolina (US): Family Health International.

Mat Sharif, Z. B., Mohd Taib, N. B., Yusof, M. S., Rahim, M. Z., Mohd Tobi, A. L., \& Othman, M. S. (2017). Study on handing process and quality degradation of oil palm fresh fruit bunches. Mechanical Engineering, Science and Technology International Conference. IOP Conf. Series: Materials Science and Engineering. 203: 1-10.

Montedo, U. B., \& Abrahão, J. I. (2015). The process of developing new competences: A case study at a family agricultural production unit. Production. 25(2), 336-343.

Munthali, K. G., \& Murayama, Y. (2013). Interdependences between smallholder farming and environmental management in Rural Malawi: A case of agriculture-induced environmental degradation in Malingunde Extension Planning Area (EPA). Land. 2, 158-175.

Nesheim, I., Barkved, L., \& Bharti, N. (2017). What is the role of agro-met information services in farmerdecision-making? Uptake and decision-making context among farmers within three case study villages in Maharashtra, India. Agriculture. 7(70), 1-16.

Nurliza, N., \& Dolorosa, E. (2017). Effect relationships on sustainable development of palm oil production for independent smallholder farmers toward sustainable. Journal of Sustainable Development. 10(1), 24-33.

Obert, S., Stewart, M., \& Desderio, C. M. (2015). Towards improving service delivery in local authorities. A case of Chegutu Municipality in Zimbabwe. OSR Journal Of Humanities And Social Science. 20(11), 55. 
Odini, S. (2014). Access to and use of agricultural information by small scale women farmers in support of efforts to attain food security in Vihiga County, Kenya. Journal of Emerging Trends in Economics and Management Sciences. 5(2), 80-86.

Odongo, D. (2014). Agricultural information access among smallholder farmers: Comparative assessment of peri-urban and rural settings in Kenya. Agricultural Information Worldwide.6: 133-137.

OECD. (2005). Integrated Environmental Permitting Guidelines For Eecca Countries. Paris (FR): Organization for Economic Cooperation and Development.

. (2007). Small business and Environmental Compliance:Review and Possible Application of International Experience in Georgia. Paris (FR): Organization for Economic Cooperationand Development.

Pe'er, G., Zinngrebe, Y., Hauck, J., Schindler, S., Dittrich, A., Zingg, S.(2016). Adding some green to the greening: Improving the EU's Ecological Focus Areas for biodiversity and farmers. Conserv. Lett. 10(5),517-530.

Penunia, E. A. (2011). The Role of Farmers' Organizations in Empowering and Promoting the Leadership of Rural Women. Accra (GH): UN Women in cooperation with FAO, IFAD and WFP.

Rojo, M. S., Moratalla, A. Z., Alonso, N. M., \& Jimenez, V. H. (2014). Pathways towards the integration of periurban agrarian ecosystems into the spatial planning system. Ecological Processes. 3(13), 1-16.

RSPO. (2016). RSPO Smallholders Definition. http://www.rspo.org/smallholders/rspo-smallholdersdefinition.

Salmiyati, Heryansyah, A., Idayu, I., \& Supriyanto, E. (2014). Oil palm plantations management effects on productivity fresh fruit bunch. APCBEE Procedia. 8, 282-286.

Saswattecha, K., Hein, L., Kroeze, C., \& Jaujit, W. (2016). Effects of oil palm expansion through direct and indirect land use change in Tapi river basin, Thailand. International Journal of Biodiversity Science, Ecosystem Services \& Management. 12(4), 291-313.

Shepherd, A. W. (2007). Approaches to Linking Producers to Markets: A Review of Experiences to Date. Rome (IT): Food and Agriculture Organization of the United Nations.

Shiferaw, B. A., Obare, G. A., Geoffrey, M., \& Silim, S. (2009). Leveraging institutions for collective action to improve markets for smallholder producers in less-favored areas. African Journal of Agricultural and Resource Economics, 3(1), 1-18.

Sugiyono. (2003). Metode Penelitian Bisnis. Bandung (ID): Alfabeta.

Taddese, A. B. (2013). Potential Impact of Land Certiification on Households' Land-Related Investment Intentions in Southern Ethiopia. Norwegia (Norway): Norwegian University of Life Sciences.

Tham-Agyekum, E. K., Appiah, P., \& Nimoh, F. (2010). Assessing farm record keeping behaviour among small-scale poultry farmers in the Ga East Municipality. Journal of Agricultural Science. 2(4), 52-62.

Tripp, R., \& Longley, C. (2006). Self-sufficient Agriculture: Labour and Knowledge in Small-scale Farming. London (GB): Earthscan.

Turner, D. W. (2010). Qualitative interview design: A practical guide for novice investigators. The Qualitative Report. 15(3), 754-760.

UNSDSN. (2013). An Action Agenda for Sustainable Development: New York, United States: The Sustainable Development Solutions Network (SDSN).

van der Enden, S. (2013). Smallholders and Sustainable Palm Oil Production: A Better Understanding between Policy Arrangements and Real-Life Practices. Rotterdam (Netherlands): Wageningen University and Research Centre.

Varkkey, H. (2015). The Haze Problem in Southeast Asia: Palm Oil and Patronage. London (GB): Routledge.

Veloo, R., van Ranst, E., \& Selliah, P. (2015). Proper understanding of oil palm development on peatland is required to achieve the implementation of sustainable practice in oil palmoperation. NJAS - Wageningen Journal of Life Sciences. 72-73, 33-40.

Vijay, V., Pimm, S. L., Jenkins, C. N., \& Smith, S. J. (2016). The impacts of oil palm on recent deforestation and biodiversity loss. PLoS ONE. 11(7).doi.org/10.1371/journal.pone.0159668. 
Vik, J., \& Stræte, E. P. (2017). Embedded Competence: A Study of Farmers' Relation to Competence and Knowledge. System Dynamics and Innovation in Food Networks.2017 (p. 392-403). Trondheim (Norway): Centre for Rural Research,.

Wheeler, D., Hammer, D., Kraft, R., \& Dasgupta, S. (2013). Economic dynamics and forest clearing: A spatial econometric analysis for Indonesia. Ecological Economics. 85, 85-96.

Wild, L., Chambers, V., King, M., \& Ha, D. (2012). Common constraints and incentive problems in service delivery. London(GB): Overseas Development Institute.

Woittiez, L. S., van Wijk, M. T., Slingerland, M., van Noordwijk, M., \& Giller, K. E. (2017). Yield gaps in oil palm: A quantitative review of contributing factors. European Journal of Agronomy, $83,57-77$.

Woolverton, A., \& Neven, D. (2014). Understanding Smallholder Farmer Attitudes to Commercialization. Rome (IT): Food and Agriculture Organization of the United Nations.

Wordofa, M. G., \& Sassi, M. (2014). Improving Smallholder Farmers' Income through Farmer Training Centers: An Impact Evaluation in Haramaya District, Ethiopia. Pavia (IT): Natural Resources, Agricultural Development and Food Security- International Research Network.Wild et.al., 2012;

Wulandari, E., Meuwissen, M. P., Karmana, M. H., \& Oude Lansink, A. (2017). Access to finance from different finance provider types: Farmer knowledge of the requirements. PLoS ONE. 12(9).doi.org/10.1371/journal.pone.0179285.

Yves, Z., Pe'er, G., Schueler, S., Schmitt, J., Schmidt, J., \& Lakner, S. (2017). The EU's ecological focus areas-How experts explain farmers' choices in Germany. Land Use Policy. 65, 93-108 